\title{
Interactions between fiscal and monetary policies: a brief history of a long relationship
}

DUBRAVKO MIHALJEK, Ph.D.*

Article $^{* *}$

JEL: E61, E63, E65, E58, E42, H63

https://doi.org/10.3326/pse.45.4.2

\footnotetext{
* The views expressed are those of the author and not necessarily those of the Bank for International Settlements, Basel, Switzerland. The author thanks Frederic Boissay, Cheng Gong, Paul Wachtel and participants of the $27^{\text {th }}$ Dubrovnik Economic Conference (July 2021) for helpful discussions, and Alberto Americo and Emese Kuruc for research assistance as well as two anonymous referees for their useful comments and suggestions.

${ }^{* *}$ Received: October 15, 2021
}

Accepted: October 31, 2021

Dubravko MIHALJEK

Bank for International Settlements, Centralbahnplatz 2, 4002 Basel, Switzerland e-mail: Dubravko.Mihaljek@bis.org ORCiD: 0000-0003-4706-9534 


\section{Abstract}

This paper compares and contrasts interactions between monetary and fiscal policies in major economies following the recent pandemic recession with selected episodes from the past, notably the Great Inflation of the 1970s, the Great Moderation of the 1990s, and the Great Financial Crisis and its aftermath. Interactions between fiscal and monetary policies in these periods were characterised respectively by the collapse of consensus about fiscal dominance, strict separation of monetary and fiscal policies, and intermittent close coordination. The paper tentatively argues that a consensus on the "new normal" for the two policies is unlikely to emerge in the near term.

Keywords: fiscal policy, monetary policy, policy coordination, policy interactions, fiscal dominance, pandemic recession, macroeconomic stabilisation

\section{INTRODUCTION}

The two prime macroeconomic powers of the state, monetary and fiscal policies, interact closely. Both have a major impact on aggregate demand and, to varying degrees, aggregate supply. Fiscal policy affects aggregate demand and supply directly through the taxes and incentives they create, by public investment, transfers to household and firms, and wages in the public sector. Monetary policy works more indirectly, primarily through the interest rate, which influences financing conditions and thereby consumption and investment. Its effects on the real sector, notably business fixed investment, are generally slower and less certain, but also more pervasive - interest rates in particular "get into all the cracks" (Stein, 2013).

In this paper the focus is on interactions between monetary and fiscal policies as macroeconomic stabilisation tools. The analysis is done in very broad strokes. Of particular interest are episodes when fiscal and monetary policies freed each other's space for action, and those when they worked at cross-purposes. Prime examples of positive interactions are coordinated global monetary and fiscal expansion after the outbreak of the Great Financial Crisis in 2008-09, and unprecedented fiscal and monetary stimulus across major economies in response to pandemic-induced lockdowns in 2020. Examples of less helpful interactions can also be found in the post-financial crisis period: with interest rates and inflation at alltime lows, a sustainable fiscal stimulus from 2012 on could have helped lift inflation in the short term and potential output in the long term. But fiscal policy was arguably too tight, stunting the recovery and shifting the burden of supporting the post-crisis recovery to monetary policy (Bernanke, 2013; Draghi, 2014).

A longer-term perspective is helpful in describing policy interactions because throughout history monetary and fiscal policies have been closely intertwined. To the extent that one can identify similarities and differences between policy roles in respective historical episodes, one can be in a better position to understand whether some issues are missing or are being overstressed in current policy discussions. This paper attempts to provide a broad background for that kind of discussion. It 
highlights the return of fiscal policy as a macroeconomic stabilisation tool during the pandemic. It also highlights the lack of consensus about the proper roles of monetary and fiscal policies in the face of some old and new challenges facing the global economy in the aftermath of the financial and pandemic crises.

The paper starts with a brief overview of monetary and fiscal policies during the Covid pandemic. The second section discusses the longstanding issue of the policy mix, illustrating it with the dilemma about the "right" amount of stimulus that many monetary and fiscal authorities face at the current juncture. The third section turns to two aspects of longer-term interactions: the issues of public debt sustainability and the dominance of fiscal over monetary policy. The concluding section provides some thoughts on what kind of consensus on the two policies might emerge.

\section{MONETARY AND FISCAL POLICIES DURING THE COVID PANDEMIC}

As the recession induced by lockdowns in 2020-21 unfolded, monetary and fiscal policy worked closely together to cushion the pandemic's economic fallout. Monetary policy stabilised the financial system, kept credit flowing and eased financing conditions more generally. Fiscal policy shielded firms and households through transfers and loan guarantees. In the process, both policies supported each other. Large-scale central bank purchases of sovereign debt eased government financing constraints, and fiscal backstops and guarantees leveraged the central bank's lending power.

The combined stimulus provided by monetary and fiscal authorities was unprecedented. Fiscal support reached in aggregate over 9\% of world GDP (around $\$ 10$ trillion) as of March 2021. Among advanced economies, Australia, Canada, Japan, the United Kingdom and the United States provided the largest support, from 17 to $26 \%$ of GDP over 2020-21 (graph 1, left-hand panel). In Europe, the fiscal push was smaller, 7-11\% of GDP, supplemented from mid-2021 by multiyear grants from the Next Generation EU Fund. In emerging market economies, the support was generally smaller, but nonetheless substantial: Brazil managed to provide $12 \%$ of GDP in fiscal support; China, Korea and South Africa close to 7\%; and many others up to $5 \%$ (right-hand panel).

Monetary stimulus was no less forceful. Many central banks cut policy rates to all-time lows, often close to or below zero (graph 2, left-hand panel). They also deployed unconventional tools - large-scale asset purchases, special lending programmes, forward guidance, yield curve control - including in many emerging market economies (centre panel). As a result, the size of the major central banks' balance sheet is at a historical high in most countries (right-hand panel), largely because of an increase in the holding of government securities. 

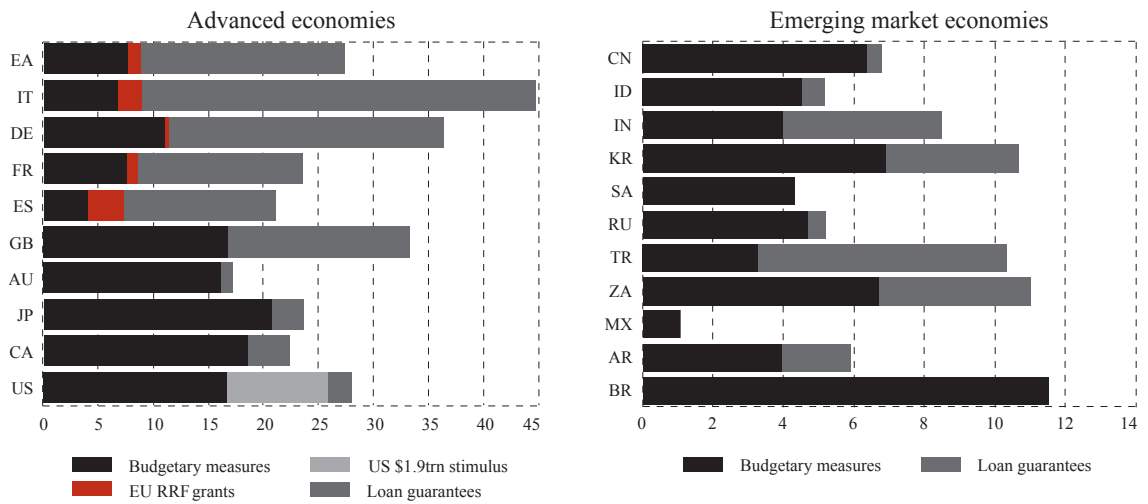

${ }^{1}$ Including health and non-health related spending measures announced through March 2021, based on IMF's Fiscal Policies Database. For the European Recovery and Resilience Facility, $50 \%$ of grants assumed to be spent in 2021.

Sources: European Commission; IMF, Fiscal Policies Database; OECD; author's calculations.

\section{GraPh 2}

Monetary stimulus during the pandemic
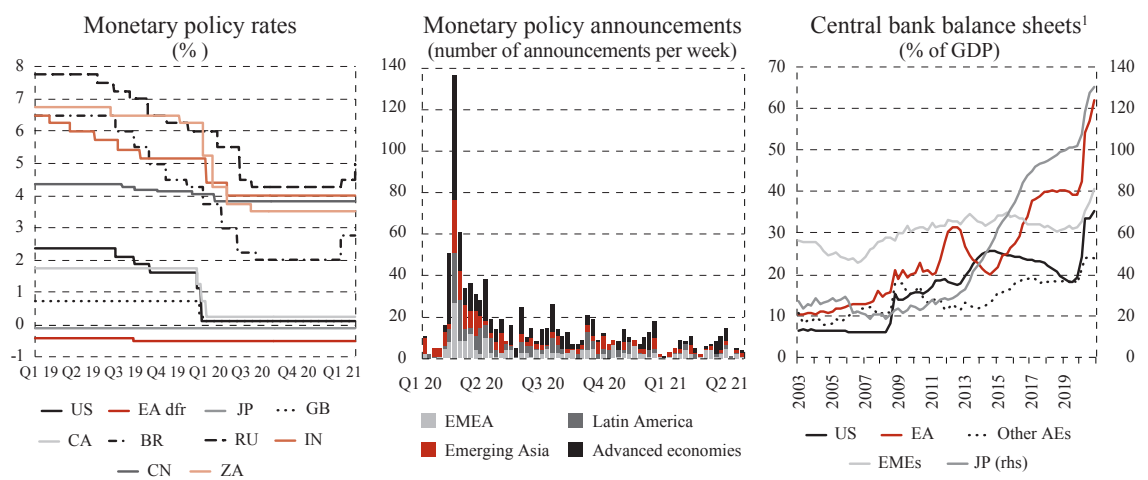

${ }^{1}$ Total assets; median values for eight advanced economies (AEs) and 22 emerging market economies (EMEs). EMEA = emerging Europe, Middle East and Africa.

Sources: IMF; national data; BIS, Database on monetary policy announcements during Covid-19; Cantu et al. (2021).

The active role of fiscal policy in response to the pandemic shock is noteworthy because academic work and policy analysis had advocated against such stabilisation function ever since the 1970s' Great Inflation. This view was reflected in leading textbooks: Mankiw and Taylor (2011), for instance, highlighted long and uncertain lags in the implementation of tax and spending measures, and the consensus view that automatic stabilisers were far more effective for macroeconomic stabilisation over the business cycle than discretionary fiscal measures. That said, they acknowledged that automatic stabilisers were generally not sufficiently strong to prevent 
recessions completely, and argued against a strict balanced budget rule, which could, in effect become an "automatic destabiliser" (ibid, 778).

The rebound of the global economy since mid-2020 suggests that the combined monetary and fiscal stimulus has been effective so far. However, the unprecedented size of the stimulus has raised a number of questions, including about the calibration of the policy mix in the short-term, the longer-term consequences of stimulus for individual countries and the global economy, and the nature of interactions between fiscal and monetary policies in an elusive "new normal" regime that has yet to emerge after the financial crisis.

\subsection{SHORT-TERM INTERACTIONS}

In the short term, monetary and fiscal policies interact mainly through their respective stances. The "right" policy mix depends on the stage of the business and financial cycle and the structure of the economy. At the current post-pandemic recession juncture, the key question is whether monetary and fiscal policies are doing "too little" or "too much" to support the recovery, i.e., whether they are withdrawing support too early or providing it for too long. Given that monetary policy has by and large reached the limits of its expansionary stance, this has mainly been a question about the "right" fiscal policy stance.

\subsection{NOT ENOUGH STIMULUS?}

The main risk of withdrawing stimulus too early is that the recovery will falter. The pandemic is far from over, and growth is still fragile and very uneven across sectors, regions, and countries. Recent output gap projections point to sizable slack until 2023 in most countries, especially where fiscal stimulus was modest (IMF, 2021a). Withdrawing fiscal stimulus too early would put pressure on monetary policy to close output gaps. That would probably delay the recovery because monetary policy alone is not as powerful as when it works together with fiscal policy. With interest rates already at the effective lower bound, monetary policy would have to rely on unconventional tools, which tend to become less effective over time. ${ }^{1}$ The double-dip recession after the Great Financial Crisis, when fiscal policy in the United States turned too restrictive because of domestic political tensions, and in Europe because of the sovereign debt crisis, are recent examples.

Another risk of early withdrawal of fiscal stimulus and prolonged reliance on monetary policy could be excessive risk taking in the financial sector. This risk arose for instance during the Great Financial Crisis. Forward guidance, yield curve control and, to some extent, large-scale asset purchases typically induce investors to search for yield, which tends to heighten financial market volatility.

\footnotetext{
${ }^{1}$ Early rounds of central bank purchases of a given asset class seem to be more effective in reducing longterm yields than subsequent rounds (Krishnamurthy and Vissing-Jorgensen, 2013). Other studies find, however, that the sheer announcement of asset purchases works to reduce the eligible assets' credit spreads by up to four times as much as the actual purchases (Gilchrist et al., 2020). This suggests that, if credible, central bank communication policies may help reduce the ultimate size of asset purchases.
} 
Market participants also become highly sensitive to threshold effects of policy revisions, such as perceived interest rate "lift-off". A case in point is the "taper tantrum" episode in mid-2013, when US Treasury yields increased sharply after the Federal Reserve announced that, at some future date, it would reduce the volume of bond purchases under its quantitative easing programme.

In addition, asset valuations can become overstretched with prolonged monetary stimulus. For instance, equity prices increased sharply in most advanced economies during 2020-21 despite the fragile and uneven recovery. House prices were rising fast as well, partly due to demand factors (shift to work from home), partly due to lower interest rates and fiscal support, which helped households maintain their debt servicing capacity. These developments could lead to sharp corrections in equity and house prices if fiscal stimulus is withdrawn too early and monetary policy becomes "the only game in town", as was the case in 2012-13 (Rajan, 2013).

Withdrawing fiscal stimulus too early could also harm the prospects for raising potential growth. Public investment in education, transportation infrastructure, energy and telecommunications, digital and green technologies could catalyse private investment in these areas and help boost productivity growth over the medium term. Recent estimates suggest that well-targeted public investment of $1 \%$ of GDP can raise output over four years by 0.5 percentage points in emerging market economies, and 1.2 points in advanced economies (IMF, 2020). If productivity growth is sustained over a longer period, public investment could help raise the natural interest rate, $r^{*}$, as well, thereby creating room for monetary policy manoeuvre. Productivity-enhancing investments are also needed because prolonged lockdowns could lead to labour skill losses ("hysteresis effects"), which could be larger than in "normal" recessions in the sectors hit particularly hard by the pandemic. This could increase the risk of staying trapped in the regime of low potential growth, which characterised most of the post-GFC decade.

\subsection{TOO MUCH STIMULUS?}

The main risk of providing "too much" stimulus is that the economy overheats and inflation becomes hard to control. This was the case in the 1960s and 1970s, when many advanced economies experienced stagflation - stagnating growth with rising unemployment and inflation. One inflationary impulse at the time came from the 1973 oil price shock. Two others, more persistent, came from expansionary public spending and high wage demands of trade unions. Highly regulated economies and pervasive financial repression aggravated the situation and complicated policy choices. To cushion the rise in unemployment and the fall in real income, fiscal and monetary policies turned expansionary. Budget deficits, public debt and money supply increased rapidly, and real interest rates fell or turned negative for much of the 1970s. Many governments found it increasingly difficult to finance growing budget and balance of payments deficits. The UK government, for instance, approached the IMF in September 1976 for a loan of \$3.9 billion, the largest amount ever requested from the Fund until then. 
Stagflation ended only after central banks regained credibility by tightening monetary policy and bringing down inflation, and after fiscal authorities started the long, arduous process of fiscal consolidation. The latter included changes in the tax system (including expansion of the value-added tax and reduction of harmful progressivity of the income tax); privatisation of loss-making public enterprises (to reduce expenditure); and deregulation of the economy and domestic financial liberalisation (to raise potential growth and wind down financial repression). Countries such as Germany and Switzerland, which maintained prudent fiscal policies and swiftly adopted a new nominal anchor - monetary targeting - after the collapse of Bretton Woods largely succeeded in escaping the great inflation. Their success partly paved the way for emphasis on stable public finances along with central bank independence and the anchoring of inflation expectations under inflation targeting.

Currently, the prospect of such 1970s-style stagflation seems remote. The recent rise in inflation seems to reflect for the most part one-off factors - base effects, indirect tax changes, increases in commodity and food prices, constrained supply and logistics (IMF, 2021b). With the exception of China and the United States, output gaps in major economies are not projected to be closed in the next two years. Recent empirical evidence based on historical data also suggests that even large fiscal expansions generate only modest inflation (Hazell et al., 2021). Importantly, fiscal expansion and upward revisions of growth forecasts in advanced economies have not lifted market participants' expectations of inflation over the medium term.

Nevertheless, pent-up demand from excess saving during lockdowns and fiscal stimulus could lead to overheating in some cases. One reason is that fiscal multipliers tend to be much larger when policy rates are at effective lower bound (Klein and Winkler, 2021; Amendola et al., 2019). Fiscal policy thus has to intervene more aggressively to compensate for less potent monetary policy, leading to higher and more volatile public debt (Hofmann et al., 2021). This effect is not limited to advanced economies. In Chile and Peru, for instance, authorities allowed the withdrawal of household savings accumulated in defined-contribution pension funds. Consistent with the notion that poorer households tend to have a higher marginal propensity to consume and that transfers to such households deliver higher spending multipliers, this has led to somewhat higher inflation than in countries where a proportionately greater share of fiscal support went to firms. ${ }^{2}$

In emerging market economies, an additional consideration is the threat of exchange rate depreciation and capital outflows. If inflation pressures persist, monetary easing could lead to further capital outflows (Banerjee et al., 2020). Central banks may thus be forced to raise interest rates. However, this may make domestic debt even less attractive to foreign investors and lead to further currency depreciation, given that higher domestic interest rates aggravate debt sustainability problems (Blanchard, 2004).

\footnotetext{
${ }^{2}$ Recent estimates, for instance, suggest that financially constrained recipients of one-off transfers (such as paychecks) spend $62 \%$ of the payment within two weeks, against 35\% for unconstrained recipients (Karger and Rajan, 2020).
} 


\section{LONG-TERM INTERACTIONS}

In the longer term, interactions between monetary and fiscal policies face further challenges, notably from high public debt and threats to central bank independence, i.e., the risk of return to some form of fiscal dominance.

\subsection{WILL PUBLIC DEBT REMAIN SUSTAINABLE?}

The current juncture partly reflects deeper trends that the pandemic has exacerbated. Fiscal expansion in many countries took place from an already historically high level of public debt: overall fiscal deficits reached 12\% of GDP on average in advanced economies and 10\% in emerging market economies in 2020 (table 1). Global public debt stock climbed above $100 \%$ of GDP, more than 10 percentage points higher than before the pandemic. The increase was facilitated by central banks, which lowered policy rates and purchased government bonds in pursuit of their mandates, and, in some countries, larger public debt holdings by the domestic banking system.

\section{TABLE 1}

Government balance and public debt (as a percentage of GDP)

\begin{tabular}{|c|c|c|c|c|c|c|}
\hline & \multicolumn{3}{|c|}{ General government balance } & \multicolumn{3}{|c|}{ Gross public debt } \\
\hline & 2019 & 2020 & 2021 & 2019 & 2020 & 2021 \\
\hline Euro area & -0.6 & -7.6 & -6.7 & 84 & 97 & 98 \\
\hline France & -3.0 & -9.9 & -7.2 & 98 & 114 & 115 \\
\hline Germany & 1.5 & -4.2 & -5.5 & 60 & 69 & 70 \\
\hline Spain & -2.9 & -11.5 & -9.0 & 96 & 117 & 118 \\
\hline Italy & -1.6 & -9.5 & -8.8 & 135 & 156 & 157 \\
\hline Japan & -3.1 & -12.6 & -9.4 & 235 & 256 & 257 \\
\hline United Kingdom & -2.3 & -13.4 & -11.8 & 85 & 104 & 107 \\
\hline United States & -5.7 & -15.8 & -15.0 & 108 & 127 & 133 \\
\hline Brazil & -5.9 & -13.4 & -8.3 & 88 & 99 & 98 \\
\hline China & -6.3 & -11.4 & -9.6 & 57 & 67 & 70 \\
\hline India & -7.4 & -12.3 & -10.0 & 74 & 90 & 87 \\
\hline South Korea & 0.4 & -3.1 & -2.7 & 42 & 48 & 53 \\
\hline Mexico & -2.3 & -4.6 & -3.4 & 53 & 61 & 61 \\
\hline Russia & 1.9 & -4.1 & -0.8 & 14 & 19 & 18 \\
\hline Turkey & -6.4 & -7.4 & -7.1 & 32 & 40 & 40 \\
\hline South Africa & -5.3 & -12.2 & -10.6 & 62 & 77 & 81 \\
\hline
\end{tabular}

Source: IMF (2021c).

At the same time, nominal interest rates have never been so low, and in real terms they have been negative for even longer than during the Great Inflation (BIS, 2021). Despite record-high debt-to-GDP ratios, service costs are thus at post-war lows and the debt burden seems very light. This does not mean that debt sustainability issues are unimportant. Fiscal sustainability depends on the joint dynamics of the recovery and financing conditions for governments. If the recent optimistic growth expectations materialise, growth in GDP could replenish the tax base, enlarge fiscal space, and help deal with the rising nominal debt. The decline in real 
interest rates, which predated the pandemic recession, also helps generate a sustainable debt trajectory. Other secular trends - including slower population growth and longer duration of retirement, which strengthen the propensity to save - also suggest that real interest rates may remain low in the medium term (Furman and Summers, 2020). If so, government debt rollover may not call for outsized future tax increases or spending consolidation.

Favourable refinancing conditions cannot be taken for granted, however. In the longer term, the aging of the population will likely increase public debt burden through higher primary deficits, especially in countries with pay-as-you-go pension schemes. Larger debt exposes the economy to multiple equilibria because differentials between real interest rates $(r)$ and real growth rates $(g)$ are sensitive to the initial government debt level (Cochrane, 2021). Countries with higher initial public debt thus tend to experience a shorter duration of negative $(r-g)$ episodes, and larger increases in interest rates in response to greater financial market volatility. For instance, a 1 percentage point increase in debt/GDP in emerging market economies is associated with an almost 0.4 percentage points increase in $(r-g)$ when the legacy public debt exceeds $70 \%$ of GDP (Lian, Presbitero and Wiriadinata, 2020). These non-linearities may be explained by the self-reinforcing mechanism between risk premia and debt levels, which can lead to significantly different debt paths (i.e., multiple equilibria) even if the initial conditions change only marginally. Market sentiment can change particularly abruptly for countries that depend on external financing.

\subsection{THREAT OF FISCAL DOMINANCE?}

The second longer-term challenge for monetary-fiscal interactions is the risk of fiscal dominance. In broadest terms, fiscal dominance denotes a situation in which monetary policy is subordinated to fiscal policy objectives. This was the case, for instance, in advanced economies from the Great Depression in the mid-1930 until the collapse of the Bretton-Woods fixed exchange rate system in the early 1970s. In this period, central banks routinely engaged in financial repression to allow governments to issue debt at low interest rates, and often directed cheap credit to targeted industries or firms so as to fulfil their own economic objectives. These practices included capping interest rates, imposing high reserve requirements on banks, requiring banks to hold government debt via capital requirements, regulating competition in the banking sector, restricting international capital movements, and other measures that kept nominal interest rates typically below the rate of inflation. To the extent that interest rates were adjusted for other objectives, this was mainly at times of balance of payments pressures.

Interestingly, financial repression is also associated with the "golden age" of European growth from 1950 to 1973. In this period, authorities in countries such as France and Italy established a range of public and mixed ownership institutions specialised in credit allocation to targeted industries (Monnet, 2012). Economic growth and financial repression thus went hand in hand for a quarter century, without negative consequences being becoming apparent until the outbreak of inflation in the mid-1970s. 
Since the liberalisation of financial markets in the 1980s and widespread achievement of central bank independence in the 1990s, fiscal dominance has come to denote a situation in which monetary policy cannot be tightened because of the interest rate sensitivity of debt service costs. Strong institutional safeguards designed to shield the central bank's operational autonomy can be effective when pressures are purely of a political nature. But they can do relatively little when the constraint is economic. For instance, in emerging market economies higher interest rates to counter inflation may undermine the government's creditworthiness, especially where debt is at floating rates. This can trigger a disruptive capital outflow, a sharp currency depreciation, and even higher inflation.

Fiscal constraints can also tie the central bank's hands in advanced economies. One example is the sovereign debt crisis in Europe in 2011-12, when the loss of market access for some governments disrupted the transmission mechanism of monetary policy in the euro area and gave rise to currency denomination risk. Another is the sovereign-bank nexus: in a fiscal crisis, banks holding large amounts of government bonds are exposed to distress or outright crisis. Banking crises in turn lead to large fiscal costs and big increases in sovereign debt, typically in the order of 20-25\% of GDP over a five-year window (Laeven and Valencia, 2018). Fragilities in the non-financial corporate sector can further aggravate matters if domestic banks are heavily exposed to it.

To what extent could large-scale central bank purchases of government debt, conducted as part of quantitative easing operations, heighten the risk of fiscal dominance? How far could such measures blur the boundaries between monetary and fiscal policies?

From the perspective of the consolidated public sector balance sheet, government bond purchases under quantitative easing programmes are equivalent to large debt management operations: the public sector retires long-term government debt from the secondary bond market and replaces it with overnight debt, i.e., interest-bearing central bank reserves (Blommestein and Turner, 2012). The distinguishing element of monetary financing is the explicit link to fiscal deficits and governance arrangements whereby the finance ministry decides the size, time and duration of central bank bond purchases. That link is missing in the case of quantitative easing. Central banks have undertaken bond purchases in the context of a surge in government borrowing needs, with a view to keeping sovereign bond markets liquid and functional, and supporting the smooth financing of emergency fiscal spending. Such operations are fully in line with central banks' primary objectives of safeguarding macroeconomic and financial stability (Bailey, 2020). Importantly, central banks have retained full control over such operations and can unwind them as economic circumstances require.

A related question that has attracted considerable attention in academic literature is whether the form of deficit financing itself matters for inflation outcomes. 
According to monetarists, monetising a deficit results in a higher rate of inflation than bond financing. However, Sargent and Wallace (1981) derived conditions under which bond financing could lead to higher long-run inflation. Under such "unpleasant monetarist arithmetic", tightening current monetary conditions requires higher growth of interest-bearing debt. Because the government must eventually pay primary deficits and the increase in debt and accumulated interest, the central bank has to raise the money supply at some point. This results in higher inflation than if the central bank had not resorted to tightening in the first place. A valuable insight of this analysis is that fiscal dominance is generally higher where the creditworthiness of the sovereign is weaker, not stronger.

\section{CONCLUDING REMARKS}

How is the relationship between fiscal and monetary policies likely to evolve after the pandemic? Will the complementarity forged during the anti-recession effort in 2020-21 endure? Or will the two policies separate again, as they did during the Great Moderation?

In the years ahead, regaining room for manoeuvre will be important for both policies. The above analysis suggests that for some central banks the relationship with fiscal policies may have become "too close for comfort" (Weidmann, 2020). One scenario is thus a return to some form of separation between the two policies. Fiscal authorities will need to ensure public debt sustainability, and central banks will need to continue fulfilling their stability mandates. This implies that the two policies could at times work at cross-purposes, with fiscal consolidation putting pressure on monetary policy to remain easy, and monetary policy normalisation putting pressure on government borrowing costs.

Uncertainty about the respective roles of monetary and fiscal policies is thus likely to stay with us for some time. As noted above, interactions between them have typically swung from periods of consensus to those of uncertainty about the relationship. Goodhart (2016) identified two periods of consensus since the Second World War: about fiscal dominance (through the early 1970s); and about the separation of two policies, i.e., independent central banks and inflation targeting on the one hand, and prudent fiscal policy, possibly supported by fiscal rules, on the other (mid-1980s to 2007). There were also two periods in which central banks searched for consensus: stagflation in the 1970s; and financial instability, slow growth and low inflation after the Great Financial Crisis. Innovations in central bank policies introduced after the crisis - balance sheet policies and macroprudential measures - have strengthened the monetary policy toolkit and are likely to remain part of it in the future. But as discussed above, they also carry some risks for central banks' decision-making autonomy.

The disruptions caused by the Covid pandemic have added a new element of uncertainty to this relationship, notably the recent rise in inflation. Although this increase is currently seen as temporary, it complicates the plans for policy 
normalisation. In addition, new challenges have been added to policy agendas: addressing the rise in inequality and climate related risks, among others. The expectations about what central banks in particular can do are thus not likely to diminish (Bartscher et al., 2021). This might create additional strains for the relationship between monetary and fiscal policies, as they cannot deliver on these expectations without the help of structural economic policies.

\section{Disclosure statement}

No potential conflict of interest was reported by the author. 
1. Amendola, A. [et al.], 2019. The euro-area government spending multiplier at the effective lower bound. IMF Working Paper, No. 19/133. https:/doi.org/ 10.5089/9781498314947.001

2. Bailey, A., 2020. Bank of England is not doing 'monetary financing'. Financial Times, April 5, 2020.

3. Banerjee, R. N. [et al.], 2020. Inflation at risk in advanced and emerging market economies. BIS Working Papers, No. 883.

4. Bartscher, A. [et al.], 2021. Monetary policy and racial inequality. CEPR Discussion Paper, No. 15734.

5. Bernanke, B., 2013. Statement before the Committee on Financial Services. US House of Representatives, 17 July.

6. BIS, 2020. A global sudden stop. In: Annual Economic Report 2020, Chapter I. Basel: Bank for International Settlements.

7. BIS, 2021. Covid and beyond. In: Annual Economic Report 2021, Chapter I. Basel: Bank for International Settlements.

8. Blanchard, O., 2004. Fiscal dominance and inflation targeting: lessons from Brazil. NBER Working Paper, No. 10389. https://doi.org/10.3386/w10389

9. Blommestein, H. and Turner, P., 2012. Interactions between sovereign debt management and monetary policy under fiscal dominance and financial instability. BIS Papers, No. 65.

10. Cantu, C. [et al.], 2021. A global database on central banks' monetary responses to Covid-19. BIS Working Papers, No. 934.

11. Cochrane, J. H., 2021. $r<$ g. Hoover Institution, Stanford University, July.

12. Draghi, M., 2014. Unemployment in the euro area. Speech at the Annual central bank symposium in Jackson Hole, 22 August.

13. Furman, J. and Summers, L., 2020. A reconsideration of fiscal policy in the era of low interest rates. Brookings Institution discussion draft, November.

14. Gilchrist, S. [et al.], 2020. The Fed takes on corporate credit risk: an analysis of the efficacy of SMCCF. NBER working paper, No. 27809. https://doi. org/10.3386/w27809

15. Goodhart, C., 2016. Whither central banking? In: Central banking in times of change. Vienna: Oesterreichische Nationalbank, pp 29-31.

16. Hazell, J. [et al.], 2020. The slope of the Phillip curve: evidence from US states. NBER Working Paper, No. 28005. https://doi.org/10.3386/w28005

17. Hofmann, B. [et al.], 2021. Fiscal-monetary policy interactions in a low interest rate world. BIS Working Papers, No. 954.

18. IMF, 2021a. World Economic Outlook (April). Washington: International Monetary Fund.

19. IMF, 2021b. World Economic Outlook (October). Washington: International Monetary Fund.

20. IMF, 2021c. IMF Fiscal Monitor (April). Washington: International Monetary Fund. 
21. Karger, E. and Rajan, R., 2020. Heterogeneity in the marginal propensity to consume: evidence from Covid-19 stimulus payments. Federal Reserve Bank of Chicago Working Paper, No. 2020-15. https://doi.org/10.2139/ssrn.3612828

22. Klein, M. and Winkler, R., 2021. The government spending multiplier at the zero lower bound: international evidence from historical data. Journal of Applied Econometrics, 36(6), pp 744-59. https://doi.org/10.1002/jae.2835

23. Krishnamurthy, A. and Vissing-Jorgensen, V., 2013. The ins and outs of LSAPs. In: Global dimensions of unconventional monetary policy. Economic Policy Symposium, Jackson Hole, August.

24. Laeven, L. and Valencia, F., 2018. Systemic banking crises revisited. IMF Working Paper, No. 18/206. https://doi.org/10.5089/9781484376379.001

25. Lian, W., Presbitero, A. and Wiriadinata, U., 2020. Public debt and r-g at risk. IMF Working Paper, WP/20/137. https://doi.org/10.5089/9781513550794.001

26. Mankiw, G. and Taylor, M., 2011. Economics. Cengage Learning EMEA.

27. Monnet, E., 2012. Financing a Planned economy: institutions and credit allocation in the French golden age of growth, 1954-1974. Berkeley Economic History Laboratory Working Paper, September. https://doi.org/10.2139/ssrn.2318396

28. Rajan, R., 2013. A step in the dark: unconventional monetary policy after the crisis. Andrew Crockett Memorial Lecture, BIS, 23 June.

29. Sargent, T. and Wallace, N., 1981. Some unpleasant monetarist arithmetic. Federal Reserve Bank of Minneapolis Quarterly Review, Fall. https://doi.org /10.21034/qr.531

30. Schwartz, G. [et al.] eds, 2020. Well spent: how strong infrastructure governance can end waste in public investment. Washington: International Monetary Fund. https://doi.org/10.5089/9781513511818.071

31. Stein, J., 2013. Overheating in credit markets: origins, measurement, and policy responses. Speech at a Federal Reserve Bank of St. Louis Research Symposium, 7 February.

32. Weidmann, J., 2020. Too close for comfort? The relationship between monetary and fiscal policy. Speech at the OMFIF Virtual Panel, 5 November. 